Ilmu Pertanian (Agricultural Science)

Vol. 4 No. 3 December, 2019: 110-116

Available online at http://journal.ugm.ac.id/jip

DOI: doi.org/10.22146/ipas.39676

\title{
The Growth, Production, and Quality of Shallot at Inland Quartz Sands (Quarzipsamments) in the Off Season
}

\author{
Anang Firmansyah and Andy Bhermana \\ Balai Pengkajian Teknologi Pertanian (BPTP) Kalimantan Tengah \\ Jln. G. Obos Km. 5, Menteng, Palangka Raya, Kalimantan Tengah 73112, Indonesia \\ *Corresponding author: andybhermana@yahoo.com
}

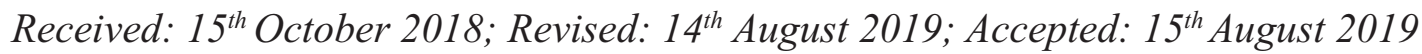

\begin{abstract}
The development of shallot cultivation on inland quartz sand during rainy or off season can be considered as new innovation. This study aimed to obtain shallot cultivars that are adaptive in terms of growth, production, and quality. The research was conducted during off season in Palangkaraya. 4 cultivars (Maja Cipanas, Tajuk, Bauji and Bima Brebes) were arranged in randomized complete block design (RCBD) $4 \times 3$ with . Minipit showed that soil bulk density increased with the deepening of the soil, however soil water content decreased. Cultivar Tajuk showed significantly different compared to Bima Brebes, with plant height of $46.88 \mathrm{~cm}$ and $39.52 \mathrm{~cm}$, number of leaves of 70.7 and 35.27 , and number of shoots of 13.43 and 6.60, consecutively. For yield components, the bulb weight of cultivar Maja Cipanas, Bauji and Bima Brebes was 10 grams heavier than that of cultivar Tajuk reaching weight of $6.97 \mathrm{~g}$ only. The production of cultivar Tajuk was low and not significantly different from cultivar Bima Brebes, reaching a yield of 15.28 ton.ha ${ }^{-1}$ and 13.31 ton.ha ${ }^{-1}$, respectively. Meanwhile, cultivar Bauji showed the highest dry production of 22.4 ton. $\mathrm{ha}^{-1}$ although it was not significantly different from cultivar Maja Cipanas producing dry production of 18.49 ton.ha- ${ }^{-1}$. In the terms of yield quality, cultivar Bima Brebes showed the optimum results in hardness of the bulbs and total dis-solved solids (TDS), with the value of $4.9 \mathrm{~kg} . \mathrm{cm}^{-2}$ and $16.42 \%$ respectively.
\end{abstract}

Keywords: Allium cepa L, back quartz sand soil, off season

\section{INTRODUCTION}

Shallot (Allium cepa L., var. aggregatum) is a plant that has high adaptability. Some varieties derived from highlands and medium can be adapted in the lowlands (Kusmana et al., 2009). Shallot can be cultivated on Alluvial soils (Firmansyah et al., 2015; Sumarni et al., 2012), coastal sandy soils (Swasono, 2012), and peatlands (Satsijati \& Koswara 1993; Firmansyah et al., 2014).

Sandy soils can be distinguished based on the location, namely: coastal sandy soils and inland sand soils. The coastal sandy soils mostly found in the beach areas, while the inland sand soils usually found far from the beach. Palangkaraya, where the study was conducted, is dominated by quartz sand soil with total area of 100,033 ha $(37.6 \%)$ (BPS, 2014), and the distance from the nearest beach in the Java sea is more than $100 \mathrm{~km}$.
The growth of shallot on the sand soils is generally constrained by the low fertility and the physical soil properties, including high porosity with low ability to retain ground water. The cultivation of shallot during the off season or rainy season is a strategy to anticipate the lack of shallot since many farmers in Java change over to paddy field. The obstacles faced by new areas for shallot development include the lack of data of cultivars that are able to adapt well in terms of growth, yield, and quality of bulbs produced.

The study was expecting to obtain adaptive cultivars of shallot in the terms of growth, yield, and quality of bulbs on quartz sandy soil in off seasons. The objective of this study was to determine the ability of four cultivars of shallot to adapt on quartz sand soil located on peat soil during rainy season in Palangka Raya. 


\section{MATERIALS AND METHODS}

The study was conducted during rainy season from December 2016 to February 2017. The experiment was located in the land accumulated with soils with texture of quartz sand derived from landscape of Entisol and Spodosol.

The research was arranged in a randomized completely block design (RCBD) $4 \times 3$ with four cultivars of shallot as treatments consisting of cultivar Maja Cipanas, Tajuk, Bauji, and Bima Brebes. The size of the plot design was $1 \times 2 \mathrm{~m}$, with a space of $15 \times 17 \mathrm{~cm}$. The total area of the experimental unit plot was $24 \mathrm{~m}^{2}$. Each bed was covered with silver-black plastic mulch.

The crop maintenance included regular watering, which was carried out to fulfill the water requirement and also to rinse the crops before sunrise in order to control plant disease in case of rainy night. Fungicides were applied regularly every three days at a time, with active ingredients of Mankozeb $80 \mathrm{WP}$ and Propineb. Fertilization was carried out in several basal application times, including a week before planting by broadcasting and mixing the fertilizer with the soil. Subsequent fertilizers were applied using two methods, namely watering technique at the age of 10, 17, 24, 31 DAP (days after planting) and spraying technique at the age of 20 and 30 DAP (Table 1). The doses of fertilization given are as follow: a). $\mathrm{N}(160 \mathrm{~g}), \mathrm{P}_{2} \mathrm{O}_{5}(160 \mathrm{~g}), \mathrm{K}_{2} \mathrm{O}(160 \mathrm{~g})$ (7 DAP); b). $\mathrm{N}(19.2 \mathrm{~g}), \mathrm{P}_{2} \mathrm{O}_{5}(19.2 \mathrm{~g}), \mathrm{K}_{2} \mathrm{O}$ (19.2g) (10 DAP); c). $\mathrm{N}$ (19.2g), $\mathrm{P}_{2} \mathrm{O}_{5}(19.2 \mathrm{~g}), \mathrm{K}_{2} \mathrm{O}$ (19.2g) (17 DAP); d). $\left.\mathrm{P}_{2} \mathrm{O}_{5}(19.44 \mathrm{~g}), \mathrm{K}_{2} \mathrm{O}(12.24 .2 \mathrm{~g})(20 \mathrm{DAP}) ; \mathrm{e}\right) . \mathrm{N}$ (38.4g), P2O5 (38.4g), K2O (38.4g) (24 DAP); f). P2O5 (19.44g), K2O (12.24g) (30 DAP); and N (38.4g), P2O5 (38.4g), K2O (38.4g) (31 DAP) (Table 1).

Soil physical analysis was carried out om the three layers of soil, which were $0-5 \mathrm{~cm}$, middle 5$10 \mathrm{~cm}$, below $0-15 \mathrm{~cm}$, and $15-20 \mathrm{~cm}$ at each point of representation of each cultivar of onion at 40 DAP (Firmansyah and Wigena et al., 2017). Physical analysis of the soil included bulk density and water content of the soil. The soil samples were taken using a ring sample on each layer of each soil that represent each cultivar, and soil physical properties obtained were then averaged to observe soil characteristics at the research location.

The variables of plant height, number of buds, and number of leaves at 40 DAP were observed by choosing 10 samples in each experimental unit to determine the middle values. Plant height was measured from the base of the stem parallel to the ground surface to the highest leaf within clumps of plant. The number of buds was calculated based on the number of shoots found in the sample. The number of leaves was calculated based on the number of leaves produced by each sample.

Several variables of productivity, involving yield and its components, were observed at 55 DAP, including bulb weight, fresh weight and dry weight per plot of 1 meter2. Bulb weight was calculated based on bulb weight divided by the number of bulbs within experiment plot. The fresh weight was obtained by weighing all the crops harvested in the fresh form. Meanwhile, the dry weight was obtained by weighing

Table 1. The use of shallot fertilization on the back quartz sand during off season

\begin{tabular}{|c|c|c|}
\hline $\begin{array}{l}\text { Application } \\
\text { time }\end{array}$ & $\begin{array}{l}\text { Application } \\
\text { technique }\end{array}$ & Type of fertilizer per total plot of 24 meters 2 \\
\hline $7 \mathrm{DBP}$ & Watering & Chicken manure $40 \mathrm{~kg}$, dolomite $9 \mathrm{~kg}$, NPK 16:16:16 $1 \mathrm{~kg}$ \\
\hline $10 \mathrm{DAP}$ & Watering & NPK 16:16:16 Yara Mila $120 \mathrm{~g}$ dissolved into water 16 liters \\
\hline 17 DAP & Watering & $\begin{array}{l}\text { NPK 16:16:16 Yara Mila } 120 \mathrm{~g}+\text { Nasa } 32 \mathrm{ml}+\text { Procal } 80 \mathrm{~g} \\
\text { dissolved into water } 16 \text { liters }\end{array}$ \\
\hline 20 DAP & Spraying & $\begin{array}{l}\text { MKP }\left(54 \% \mathrm{P}_{2} \mathrm{O}_{5}, 34 \% \mathrm{~K}_{2} \mathrm{O}\right) 36 \mathrm{~g}+10,8 \mathrm{~g} \mathrm{KCl} \text { White }(90 \% \\
\mathrm{K})+ \text { Liquid Fertilizer of Shrimp Materials } 3 \mathrm{ml} \text { dissolved } \\
\text { into water } 5.5 \text { liters }\end{array}$ \\
\hline 24 DAP & Watering & $\begin{array}{l}\text { NPK 16:16:16 Yara Mila } 240 \mathrm{~g}+\text { Humik acid } 24 \mathrm{~g} \text { dissolved } \\
\text { into water } 32 \text { liters }\end{array}$ \\
\hline 30 DAP & Spraying & $\begin{array}{l}\text { MKP }\left(54 \% \mathrm{P}_{2} \mathrm{O}_{5}, 34 \% \mathrm{~K}_{2} \mathrm{O}\right) 36 \mathrm{~g}+\mathrm{KCl} \text { White }(90 \% \mathrm{~K}) 11 \\
\mathrm{~g}+\text { Liquid Fertilizer of Shrimp Materials } 3 \mathrm{ml} \text { dissolved } \\
\text { into water } 5.5 \text { liters }\end{array}$ \\
\hline 31 DAP & Watering & $\begin{array}{l}\text { NPK 16:16:16 Yara Mila } 240 \mathrm{~g}+\text { Humic acid } 11 \mathrm{~g} \text { dissolved } \\
\text { into water } 32 \text { liters }\end{array}$ \\
\hline
\end{tabular}

Remark: DAP= Day After Planting 
the crops after dried for seven days. Production per hectare was used by assuming a real land area of $66 \%$.

The variables of production quality included bulb hardness and total dissolved solids (TDS). Bulb hardness was obtained by applying Pnetrometer tool to three small, medium, and large shallot bulbs, which were then searched for midpoint value of each test unit. The TDS value was determined using a Refractometer tool, which was measured in line with bulb hardness.

Rainfall data for ten days were calculated to observe and determine the areas of study during the rainy season considered as off season for planting. These data were collected from climate station with record number of 62710202 that located in BPPPK Tangkiling, Palangka Raya at 30 meters above sea level.

Data analysis was performed using variance analysis (anova). In order to determine the difference between median value of treatments, Duncan Multiple Range Test (DMRT, $\alpha=5 \%$ level) was performed. Meanwile, the soil parameters were analyzed using the midpoint and descriptive analysis.

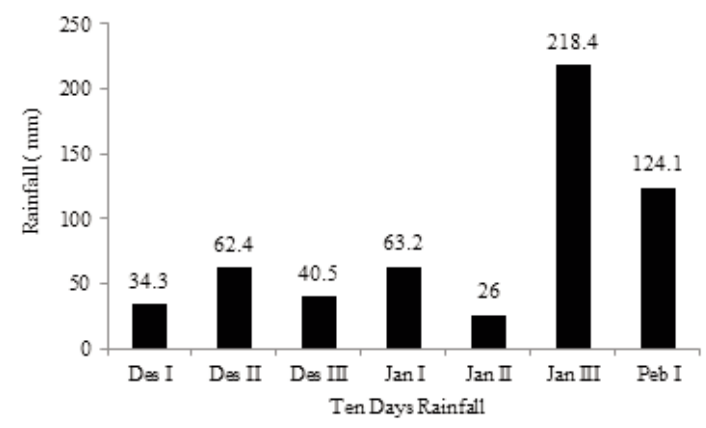

Figure 1. Rainfall and rainy days during the study

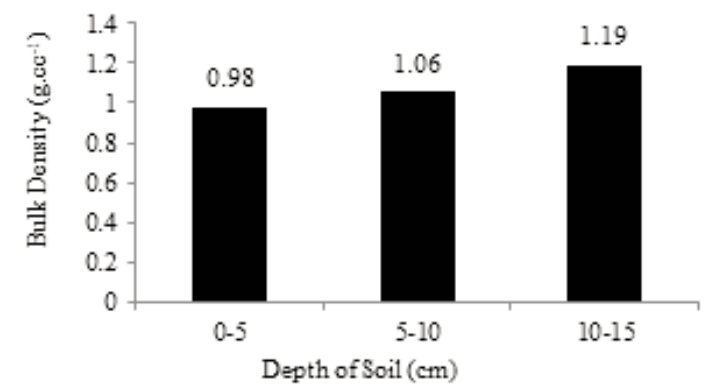

\section{RESULTS AND DISCUSSION}

\section{Rainfall and soil physical properties}

Rainfall and number of rainy days during the study was $568.9 \mathrm{~mm}$ with total number of 45 rainy days. The highest ten days rainfall on the third of January 2017 reached $218.4 \mathrm{~mm}$ with total number of 9 rainy days (Figure 1).

The application of chicken manure at a dose of 16 ton/ha was carried out on the soil surface to affect physical properties of soil. Manure accumulation on the top of soil layer will then affect the bulk density and soil water content. The bulk density and soil moisture content at research sites location for various depths of $0-5 \mathrm{~cm}, 5-10 \mathrm{~cm}$ and $10-15 \mathrm{~cm}$ were respectively 0.98 grams $/ \mathrm{cm} 3$ and $25.07 \% ; 1.06$ g.cm ${ }^{3}$ and $23.99 \% ; 1.19$ g.cm ${ }^{3}$ and $23.13 \%$ (Figure 2). Rajiman et al. (2008) added that the addition of manure 20 ton/ha could reduce the value of bulk density.

It shows that the deeper layer of sand soil, the higher value of bulk density. The high value of bulk
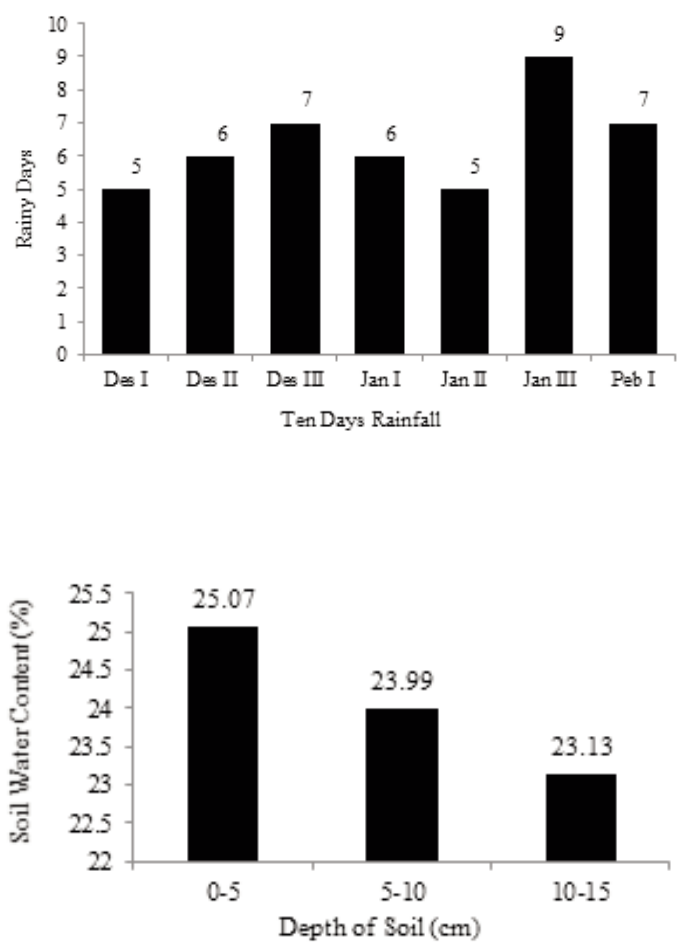

Figure 2. Bulk density and soil moisture content on various horizons in back quartz sands 
Table 2. The growth variables of several shallot cultivat ars 40 DAP on back quartz sands during off season

\begin{tabular}{lccc}
\hline Treatments & $\begin{array}{c}\text { Plant height } \\
(\mathrm{cm})\end{array}$ & $\begin{array}{c}\text { Number } \\
\text { of leaves }\end{array}$ & $\begin{array}{c}\text { Numer } \\
\text { of tillers }\end{array}$ \\
\hline Maja Cipanas & $39.97 \mathrm{a}$ & $42.50 \mathrm{ab}$ & $6.90 \mathrm{ab}$ \\
Tajuk & $46.88 \mathrm{~b}$ & $70.07 \mathrm{c}$ & $13.43 \mathrm{c}$ \\
Bauji & $42.09 \mathrm{ab}$ & $51.53 \mathrm{~b}$ & $8.63 \mathrm{~b}$ \\
Bima Brebes & $39.52 \mathrm{a}$ & $35.27 \mathrm{a}$ & $6.60 \mathrm{a}$ \\
\hline KK $(\%)$ & 19.37 & 77.70 & 9.43 \\
\hline
\end{tabular}

Remark: Means followed by the same letters in the same column are is not significantly different according to DMRT at level of $\alpha=5 \%$.

Table 3. Variables of production of several shallot cultivars at 55 DAP on back quartz sands during off season

\begin{tabular}{lccc}
\hline \multirow{2}{*}{ Cultivars } & $\begin{array}{c}\text { (Weight of tuber) } \\
\text { (g per tuber) }\end{array}$ & \multicolumn{2}{c}{ Production (ton.ha $\left.{ }^{-1}\right)$} \\
\cline { 3 - 4 } & $11.89 \mathrm{c}$ & $($ Fresh) & $($ Dry) \\
\hline Maja Cipanas & $7.44 \mathrm{a}$ & $26.73 \mathrm{~b}$ & $18.49 \mathrm{ab}$ \\
Tajuk & $7.83 \mathrm{a}$ & $30.80 \mathrm{c}$ & $15.28 \mathrm{a}$ \\
Bauji & $10.11 \mathrm{~b}$ & $19.14 \mathrm{a}$ & $13.31 \mathrm{a}$ \\
Bima Brebes & 4.97 & 12.08 & 8.53 \\
\hline KK $(\%)$ & &
\end{tabular}

Remark: Means followed by the same letters in the same column are is not significantly different according to DMRT at level of $\alpha=5 \%$.
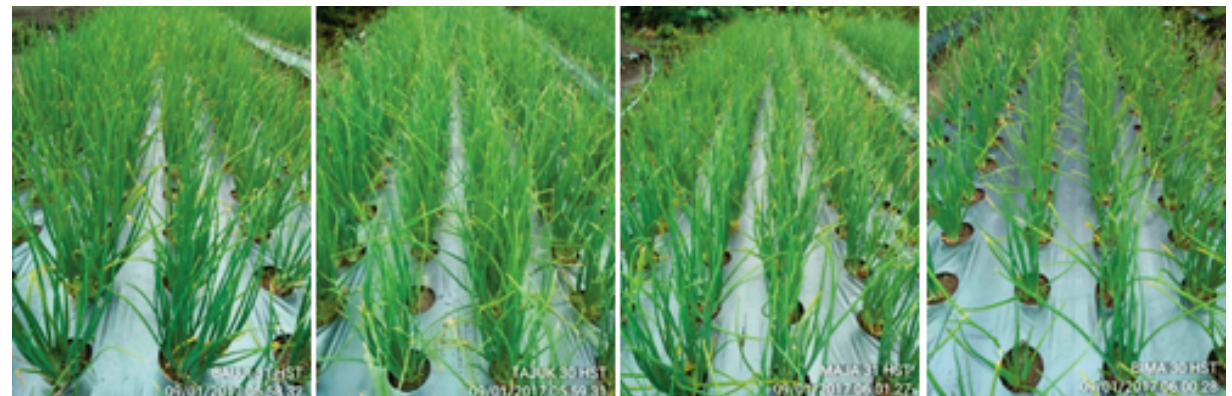

Figure 1. The appearance of agronomic characters of shallots cultivar Bauji, Tajuk, Maja Cipanas, and Bima Brebes (left to right) at 30-32 DAP

density at the bottom of soil layer is generally caused by low organic matter content, the lack of aggregation and root penetration, and compaction due to heavy load from top layer (Brady, 1990). In addition, a lot of sand soils contain macro pores so that it is difficult to hold water (Hardjowigeno 2003). Haridjaja et al. (2010) stated that a higher soil density level will affect macro pore, thereby increasing soil resistance to penetrate. It therefore affects the condition of soil water content, where the bulk density increases so that it will decrease soil water content.

\section{Variables affecting plant growth}

Based on the observation on the growth variables involving plant height, number of leaves and tillers at 40 DAP, cultivar Tajuk showed better performance comparing to the others (Table 2;
Figure 3). There were two growth variables showing significant difference compared with other varieties, i.e. number of leaves with total of 70.07 leaves and number of tillers with a total of 13.43 tillers. The large number of leaves and tillers was expected to provide relatively high production.

The number of bulbs and number of tillers, which were different between cultivars indicate the effect of genetic factors. The study conducted by Budianto et al. (2009) showed that number of bulbs was much influenced by genetic factors and less by environmental factors. The number of tillers is closely related to the size of bulbs. Shallot with large bulb size may have fewer number of tillers (Kusmana et al., 2009).

The number of leaves is assumed to be related to the number of tillers. The higher the number of tillers, the higher the number of leaves. In line with 
the study conducted by Limbongan and Monde (1999), the number of bulbs produced by shallot plant is closely related to the number of leaves. The number of leaves will affect the photosynthates produced.

\section{Variables affecting plant productivity}

According to the observation on the bulbs, cultivar Maja Cipanas, Bauji, and Bima Brebes showed larger bulbs, reaching $10.11 \mathrm{~g}$, than cultivar Tajuk that produced smaller bulbs with weight of about $7.44 \mathrm{~g}$ (Table 3). In addition to the environment, the large size of shallot bulb is affected by genetic factors. The cultivation of various cultivars at the same plot showed a variety of bulb size depending of the cultivars (Putrasamedja and Soedomo, 2007)

The productivity of various cultivars planted on inland quartz sands in Palangka Raya showed that cultivar Bauji had highest yield up to $4.67 \mathrm{~kg} . \mathrm{m}^{-2}$, which is equivalent to 30.80 ton. $^{-1} \mathrm{a}^{-1}$ with dry harvest of $3.39 \mathrm{~kg} \cdot \mathrm{m}^{-2}$ (22.40 ton.ha-1 $)$. This production is not significantly different from the production of fresh crop of cultivar Maja Cipanas and Tajuk.

It is clear that the productivity of shallot is influenced by the quantity of bulbs, which is reflected by the large number of buds and weight of bulbs produced. It can be seen on cultivar Tajuk that showed low value of bulb weight in spite of the high number of bulbs. On the other hand, cultivar Bauji showed high value of bulb weight despite the low number of bulb.

The high production of cultivar Bauji in rainy season shows that this cultivar is able to adapt in the lowland ecosystem in Palangka Raya, and it is also able to adapt well in rainy season or off session.

The shallot weight loss showed a range of $27.3 \%$ $-34.9 \%$, from fresh production to dry production. Basuki (2005) in Azmi et al. (2011) stated that different cultivars will provide different weight loss values.

\section{Variables affecting bulb quality}

Cultivar Bima Brebes showed the highest level of bulb hardness, which was significantly different from Maja Cipanas but not significantly different from cultivar Bauji and Tajuk (Table 4). The level of hardness indicates the ability in photosynthates accumulation and pectin levels in the bulbs.

The shallots with high hardness levels have a greater ability in photosynthesis, resulting in the higher accumulation of photosynthates in the bulbs, thereby increasing the bulb hardness. The hardness level of shallot was different between cultivars, indicating that the effect of genetic factors was higher than environmental factors (Anshari et al., 2011). Wibowo (2001) explained that the texture (density or hardness) of shallot bulbs was not influenced by the application of fertilizer but was more influenced by the genetic and environmental factors, including altitude, climate and soil. This has been proven by Hulzana et al. (2014) that there was no significant difference on the bulb hardness in cultivar Lembah Palu treated with different types and doses of fertilizers. As for storage, shallot bulbs that are not stored in wooden box at a room temperature have a higher hardness level compared to shallot bulbs stored in wooden box in a refrigerator at temperature of $20^{\circ} \mathrm{C}$ and RH of $65-75 \%$ (Komar et al., 2001).

Meanwhile, according to Mutia et al. (2014), bulb hardness is affected by the change of water-soluble pectin (protopectin). In addition, high hardness level is also caused by the evaporation of water in the space between cells so that the cell becomes wrinkled and fused with interconnected pectin.

The highest of Total Dissolved Solids (TDS) was shown by cultivar Bima Brebes with a value of $16.42 \%$, which was significantly different from other cultivars, while the lowest was shown by Maja Cipanas with a value of $13.34 \%$. A higher TDS

Table 4. Bulb quality of some shallot cultivars on back quartz sands during off season

\begin{tabular}{lcc}
\hline Cultivars & $\begin{array}{c}\text { Tuber hardness level } \\
\left(\mathrm{kg} \cdot \mathrm{m}^{-2}\right)\end{array}$ & Total dissolved solid (\%) \\
\hline Maja Cipanas & 3.69 & $13.34 \mathrm{a}$ \\
Tajuk & 3.97 & $15.18 \mathrm{bc}$ \\
Bauji & 4.17 & $14.76 \mathrm{ab}$ \\
Bima Brebes & 4.39 & $16.42 \mathrm{c}$ \\
\hline KK (\%) & 3.28 & 3.45 \\
\hline Remark: Means followed by the same letters in the same column are is not significantly different
\end{tabular}


content shows that potassium concentration will be increased. Cultivar Bima Brebes has the highest TDS, and it shows that cultivar Bima Brebes has better ability to absorb potassium from soil and also from leaves. Maemunah et al. (2015) added that fertilized with $150 \mathrm{~kg} \mathrm{~K}_{2} \mathrm{O}$ ha $^{-1}$, cultivar Lembah Palu showed higher TDS, reaching 19.00-23.33\%, and fertilization of $60 \mathrm{~kg} \mathrm{~K}_{2} \mathrm{O}$ ha $^{-1}$ resulted in TDS value between $17.3-19.67 \%$. Other studies have also revealed similar results. Nabi et al. (2010) furthermore explained that shallot bulb with high TDS has high absorption of potassium from the soil. TDS is an important part that determines the quality of shallot (Nabi et al., 2013). TDS contains sugar, salt and protein and other ingredients, in which sugar is more dominant. The higher TDS reflects the higher quality of shallot.

The high level of TDS can be used to predict that the onion has a stronger flavor. Based on TDS measurement, all shallot cultivars tested were excellent. It is assumed to be equal to onions, which levels of $10 \%$ or more have been excellent. Histifarina and Musaddad (1998) stated that shallot bulbs that have more dissolved solids will have a sharper aroma.

\section{CONCLUSIONS}

Cultivar Tajuk showed the best performance on growth variables, including plant height $(47 \mathrm{~cm})$, number of leaves (70 strands), and number of buds (13 tillers). Cultivar Bauji showed the best performance on yield component, including grain size of 13.86 $\mathrm{g}$ and dry production of 22.4 ton.ha $^{-1}$, which were higher compared to cultivar Tajuk with grain size of 6.79 gram and production of 15.28 ton.ha ${ }^{-1}$. Cultivar Bima Brebes showed the best adaptation in terms of quality, i.e. bulb hardness, which was $4.39 \mathrm{~kg} / \mathrm{cm} 2$ and TDS reaching $16.42 \%$. In addition, this cultivar was the most adaptive to the rainy season at the research area. Decision-making to develop shallot cultivars on inland quartz sand soils should consider the yield components.

\section{REFERENCES}

Anshari, M., Tohari., B.H. Sunarminto and E. Sulistyaningsih. 2011. Pertumbuhan, hasil dan kualitas umbi bawang merah pada kadar air tanah dan ketinggian tempat berbeda. $J$. Agrivigor, 10: 128-130.

Azmi, C., I.M. Hidayat and W. Wiguna. 2011. Pengaruh varietas dan ukuran umbi terhadap produktivitas bawang merah. J. Hort, 21:
206-213.

BPS. 2014. Kota Palangka Raya dalam Angka 2014. Badan Pusat Statistik Kota Palangka Raya.

Brady, N.C. 1990. The nature and properties of soils. 10th ed., New York: Macmillan Publishing Company.

Budianto., Aris., Ngawit dan Sudika. 2009. Keragaman genetik beberapa sifat dan seleksi klon berulang sederhana pada tanaman bawang merah kultivar Ampenan. Crop Agro, 2: 28-38.

Firmansyah, M. A. dan I. G. P. Wigena. 2017. Keragaan pertumbuhan, produksi, dan klasifikasi perakaran tiga varietas bawang merah di tanah pasir bercampur gambut. Agrisilvika, 1: 1421.

Firmansyah, M. A., I. Liferdi., N. Khaririyatun dan M. P. Yufdi. 2015. Pertumbuhan dan hasil bawang merah dengan aplikasi pupuk organik dan pupuk hayati pada tanah alluvial. J. Hort, 25: 133-141.

Firmansyah, M. A., D. Musaddad., T. Liana., M. S. Mokhtar dan M. P. Yufdi. 2014. Uji adaptasi bawang merah pada saat musim hujan di Kalimantan Tengah. J. Hort., 24: 114-123.

Hardjowigeno, S. 2003. Ilmu Tanah. Jakarta: Akademika Pressindo, Edisi Baru., Jakarta.

Haridjaja. O., Y. Hidayat dan L. S. Maryamah. 2010. Pengaruh bobot isi tanah terhadap sifat fisik tanah dan perkecambahan benih kacang tanah dan kedelai. Jurnal Ilmu Pertanian Indonesia, 15: 147-152.

Histifarina., D. Dana dan D. Musaddad. 1998. Pengaruh cara pelayuan daun, pengeringan, pemangkasan daun terhadap mutu dan daya simpan bawang merah. J. Hort, 8: 10361047.

Hulzana, M., Muhardi dan Rostati. 2014. Kualitas umbi bawang merah (Allium ascalonicum L.) varietas lembah palu pada berbagai paket perlakuan media tanam di Desa Maku Kecamatan Sigi Biromaru Kabupaten Sigi. E-J. Agrotekbis, 2: 467-473.

Komar, N., Rakhmadiono dan L. Kurnia. 2001. Teknik penyimpanan bawang merah pasca panen di Jawa Timur. Jurnal Teknologi Pertanian, 2: 79-95.

Kusmana., R. S. Basuki dan H. Kurniawan. 2009. Uji adaptasi lima varietas bawang merah asal dataran tinggi dan medium pada ekosistem dataran rendah Brebes. J. Hort., 19: 281-286.

Limbongan, J dan A. Monde. 1999. Pengaruh penggunaan pupuk organik dan anorganik terhadap pertumbuhan dan produksi bawang merah kultivar Palu. J. Hort., 9: 212-219.

Maemunah., T. Wardiyati., B. Guritno and A. N. 
Sugiarto. 2015. The influence of storage area, storage method and seed quality character on the quality of sallot seed. Int. J. Adv. Res. Biol. Sci., 2: 158-164.

Mutia, A. K., Purwanto, Y. A dan Pujantoro, L. 2014. Perubahan kualitas bawang merah (Allium ascalonicum L.) selama penyimpanan pada tingkat kadar air dan suhu yang berbeda. J. Pascapanen, 11: 108-155.

Nabi, G., A. Rab., Abbas., A J, Farhatullah., F. Munsif dan I. H. Shah. 2010. Influence of different level of potash on the quality, quality and storage life onion bulbs. J. Bot., 42: 11512163.

Nabi, G., A. Rab., Sajid., M. Farhatullah., S. J. Abba and I. Ali. 2013. Influence of curing methods and storage condition on the post-harvest quality of onion bulbs. J. Bot., 45: 455-460.

Putrasamedja, S.D. and Soedomo. 2007. Evaluasi bawang merah yang akan dilepas. Jurnal Pembangunan Pedesaan, 7: 133-146.
Rajiman., P. Yudono., E. Sulistyaningsih dan E. Hanudin. 2008. Pengaruh pembenah tanah terhadap sifat fisika tanah dan hasil bawang merah pada lahan pasir pantai Bugel Kabupaten Kulon Progo. Agrin, 12: 67-77.

Satsijati dan E. Koswara. 1993. Studi penerapan formulasi teknologi budidaya cabe dan bawang merah di lahan pasang surut. J. Hort., 3: $13-20$.

Sumarni, N., R. Rosliani dan R. S. Basuki. 2012. Respon pertumbuhan, hasil umbi, dan serapan hara NPK tanaman bawang merah terhadap berbagai dosis pemupukan NPK pada tanah Alluvial. J. Hort., 22: 365-374.

Swasono, F. D. H. 2012. Karakteristik fisiologi toleransi tanaman bawang merah terhadap cekaman kekeringan di tanah pasir pantai. Jurnal Agri Sains, 3: 88-103.

Wibowo. 2001. Budidaya bawang merah. Jakarta: Penebar Swadaya. 